\title{
Theme markedness in the translation of student translators
}

\author{
Rudy Sofyan and Bahagia Tarigan \\ Linguistics Study Program, Faculty of Cultural Sciences, University of Sumatera Utara, Medan North Sumatra, \\ Indonesia
}

\begin{tabular}{|c|c|}
\hline \multicolumn{2}{|c|}{$\begin{array}{l}\text { A good translation product should be able to reflect the typical characteristics of the target } \\
\text { language in terms of its function and structure. One of the structure features that can show that } \\
\text { the target text (TT) is free from the influence of the structure of the source language (SL) is its } \\
\text { theme structure. As there are both marked and unmarked themes, this would be considered as } \\
\text { one of the options to characterize the TT structure. This is a research-based article aimed at } \\
\text { finding out the extent of theme markedness in the student translators' TTs. This research used } \\
\text { content analysis design, taking } 15 \text { student translators as the participants. They were asked to } \\
\text { translate two news item texts from English as the source text (ST) into Bahasa Indonesia as the } \\
\text { TT. The data were collected using Translog. Based on the data analysis, it was found that: (i) } \\
\text { simple unmarked theme (SUT) was the theme most frequently used in both the ST and the TTs; } \\
\text { (ii) Indonesian news item texts were characterized by the frequent use of marked themes. This } \\
\text { finding indicates that Indonesian news item text puts more emphasis on how the events } \\
\text { presented in the text can be easily caught by the readers as SUT is characterized through the use } \\
\text { of short clauses with low lexical density. This study concludes that English and Indonesian } \\
\text { news item texts share a small number of similarities as most of their clauses are composed of } \\
\text { simple marked themes (SMT) but the similarities are outweighed by a large number of } \\
\text { differences. }\end{array}$} \\
\hline \multicolumn{2}{|c|}{ Keywords: news item text; simple and multiple theme; student translator; theme markedness } \\
\hline $\begin{array}{l}\text { First Received: } \\
27 \text { December } 2017\end{array}$ & \\
\hline $\begin{array}{c}\text { Final Proof Received: } \\
28 \text { May } 2018\end{array}$ & $\begin{array}{l}\text { Published: } \\
31 \text { May } 2018\end{array}$ \\
\hline $\begin{array}{l}\text { How to cite (in APA style): } \\
\text { Sofyan, R., \& Tarigan, B. (2 }\end{array}$ & \\
\hline
\end{tabular}

\section{INTRODUCTION}

Translation as a meaning making activity is closely related to the application of linguistic theories in its analysis. This is due to the fact that meaning is represented by a language, and a language is the focus of linguistics. One of the leading theories of linguistics concerned with the meaning of language is systemic functional linguistics (SFL). The basic analysis of SFL in translation is on how the source text (ST) is transferred to the target text (TT) without changing the original meaning or message contained in the ST from its language metafunction point of view (ideational, interpersonal and textual metafunctions).

As translation is not a matter of word-by-word transfer, textual metafunction realized through thematic structure (theme and rheme), information structure (new and given information) and cohesion (Halliday \& Matthiessen, 2004, pp. 64-90) plays a very important role in producing the good quality of TT. A good TT is a well-organized text using the typical target language (TL) style and proper TL structure. According to Ordudari (2008), a good translation should play the same role in the TL as the original did in the SL. Therefore, a TT should be read as a text commonly found in the TL. In other words, it should indicate its intertextual characteristics: the extent to which it resembles a similar text. By applying textual metafunction theory in translation, the quality of the TT is not assessed only based on the elements constructing the text, but also based on whether the TT has achieved the function intended by the ST.

\footnotetext{
* Corresponding author

Email: rudy@usu.ac.id
} 
Every type of text has its own social function leading to different generic structure and lexicogrammatical features. This study focuses its analysis on the translation of news item text from English into Bahasa Indonesia. Despite their similar social function, a small difference between English and Indonesian news item texts, such as the markedness of their theme, is also worth to study. Many studies on translation put more emphasis on the quality of translation products rather than on whether the TT achieves the same function as the ST. Nevertheless, there are also some studies trying to characterize a text type in the TL through translation studies. Nurlela, Sofyan, Gustianingsih, and Rosa (2017), for example, formulated the theme characteristics of Indonesian narrative text based on their findings on the translation of "Hikayat Deli" text from Malay into Bahasa Indonesia using an SFL approach. They found that the typical theme characteristics of Indonesian narrative text were (i) the frequent use of marked theme clauses, (ii) the frequent use of process and circumstance as the clause theme elements, (iii) the dominant use of multiple theme clauses, and (iv) the dominant use of constant continuous theme. Another study on translation trying to reveal the characteristics of theme in the TL text was done by Jalilifar (2009) who found that Persian academic texts were characterized by highly frequent use of linear patterns of thematic progression, the more frequent use of simple theme and the more frequent use of unmarked theme.

Studies on translation trying to reveal the TL text characteristics are related to revealing the translator's personality traits. As translation is both cognitive science and psychology (Munday, 2008), the effect of personality traits on the quality of translation could not be disregarded (Akbari \& Segers, 2017; Pourgharib \& Dehbandi, 2013). Particularly in translation process research, translators' personality traits are quite obvious in terms of how they handle obscurity while translating (Mellinger \& Hanson, 2017). In general, the translator's personality traits can be distinguished in terms of extraverted or introverted, sensing or intuitive, thinking or feeling, and judging or perceiving (Myers, Myers, \& Kirby, 1998).

In relation to the rationale elaborated above, studies on translation should be able to reveal typical characteristics of certain TL text type because a translation product should correspond to the applicable TL style and structure. This article is aimed at identifying the characteristics of theme markedness in English as the ST and in Bahasa Indonesia as the TT.

\section{Translation as a Written Form of Language}

Translation is a process of language transfer from the source language (SL) to the target language (TL) through the medium of writing, as Newmark (1981, p. 7) defined translation as "... attempt to replace a written message and/or statement in one language by the same message and/or statement in another language". The main point to be emphasized here is that translation is realized in the written form of language. This emphasis was also mentioned by Wilss (1982, p. 3) that translation is a transfer process aimed at transforming a written ST into an optimally equivalent TT. Although several other researchers divide translation into both written and oral translation (cf. Brislin, 1976; Dragsted, Mees, \& Hansen, 2011), the term 'translation' should be specifically addressed to written translation because oral translation is somehow closer to the term 'interpreting' in spite of everlasting debate on the issue (e.g. Chesterman, 2006).

Another point that needs to be emphasized in translation is meaning equivalence (Larson, 1984; Nida $\&$ Taber, 1969) or textual equivalence (Bell, 1991; Munday, 2008). The idea of equivalence does not pay attention to how the TT is constructed as long as it is grammatically correct and the ST original meaning is kept. Therefore, translation can be defined as a meaning equivalence in at least two languages realized in a written form of language.

\section{Translation and SFL}

In its practice, translation needs a reference based on which meaning equivalence can be well achieved. The reference refers to a theory guiding a translator in choosing the right equivalent for the meaning contained in the ST, as Chesterman and Wagner (2002, p. 7) argued that a theory can offer a set of conceptual tools that can be considered as a tool for mental problem solving in the translation process. Systemic functional linguistics (SFL) is thought of as the most appropriate theory to be applied in translation as it is a linguistic theory concerned with meaning (Halliday, 1994), and is highly relevant to translators' problems (Yallop, 1987, p. 347). In addition, Hatim (2001, p. 10) argues that SFL provides a viable and valid contribution to translation, whose products are "meaningful records of communicative events".

In an SFL paradigm, according to Halliday (1992, p. 15), a speaker is allowed to make choices from any possible potential of meaning, i.e. its system. Every form of language produced encodes different kind of meanings, which are related to the functions of language. Nevertheless, the grammatical resources responsible for realizing such meanings most often work differently across languages. Therefore, studying translation based on the SFL perspective is the best choice as translation involves at least two languages, and SFL is able to accommodate differences in all languages.

\section{Translation and Language Metafunction}

The possible meaning potential in SFL is realized in three language metafunction, namely ideational, interpersonal, and textual (Halliday \& Matthiessen, 2004, p. 24), and a translator should have competence in all of the three metafunctions in the SL and an ability to reproduce them appropriately in the TL. The ideational metafunction is realized in transitivity element (Process, Participant and Circumstance), the interpersonal 
metafunction in the mood system (Mood elements comprising Subject and Finite, and residual elements comprising Predicator, Complement and Adjunct) and the textual metafunction in Theme and Rheme (Halliday \& Matthiessen, 2004, p. 64).

The application of ideational metafunction in translation is visible through the way how the ideas in the ST are completely transferred into the TT and how processes or experiences, including actions and events, are represented in the TT (Halliday 1985, p. 53). Interpersonal metafunction, representing writer -and addressee- oriented meanings (Halliday, 2002, p. 175), considers translation as an interactive event involving the writer and readers (Ma \& Wang, 2016, p. 37). Therefore, the choice of mood system by a translator should consider the applicable mood system familiar to the TL readers. Textual metafunction concerns with the well-formed TT because it arranges disjointed "chunks" of meaning into a cohesive flow (Halliday 2002, p. 175) through thematic structure, cohesive devices and logical coherence (Halliday, 1985).

\section{Theme and Rheme}

The textual metafunction structure-theme and rheme - plays the role to confirm that the produced text is well organized. Theme as the starting point (Halliday, 1985, p. 39) or the point of departure (Martin, Matthiensen, \& Painter, 1997, p. 21-22) of the clause as a message is identified through its position in the first part of a clause, while rheme is identified as the rest of the clause in which the theme is developed (Eggins, 1994, p. 275). Through the choice of thematic clause elements, a translator can control the organization of a text. The theme comprising topical, interpersonal and textual elements (Halliday \& Matthiessen 2004, p. 79) is realized in either simple (p. 68) or multiple themes (p. 81). The former is composed of one theme element, while the latter is composed of more than one theme element. The choice of simple or multiple themes can show how the clauses are related one another.

In addition, the text organization can also be influenced by the choice of unmarked or marked topical themes (Halliday \& Matthiessen, 2004, p. 73-74). Theme markedness is organized and realized differently from language to language and functions as one of the distinctive characteristics of text types and as a reflection of the culture in which the language is embedded.

\section{METHOD}

This paper is a report of an instance of descriptive qualitative research using a content analysis as its design. The data were two source texts (ST) entitled "Philippines bank BPI hit by glitch which debited accounts" and "Apple reveals 'leap forward' iPhone X" together with their target texts (TT). Both of the STs were articles composed of 236 words published by BBC online available at http://www.bbc.com/news/business40183088 and http://www.bbc.com/news/technology-
41228126 respectively. The readability of the ST was measured using three different readability indices: Flesch Reading Ease Score (FRES), Flesch-Kincaid Grade Level (FKGL) and Simple Measure of Gobbledygook (SMOG). The results of the readability measures showed that both of the STs were fairly difficult to read and deserved to be tested to university students in the non-native English-speaking country. The research participants were 15 students majoring in English Literature in the Faculty of Cultural Sciences, University of Sumatera Utara who had taken translation courses. In this research, they are identified as student translators, or student for short. As translators should be competent in both the TL and SL, their English proficiency had been tested using TOEFL, and their lowest score was 500 .

The data were collected using Translog in which the STs and the TTs were fully recorded. In addition to complete recording of the data, the use of Translog confirmed the accuracy of the data as there was no any single textual information needed in the translation process missing. Furthermore, it facilitated the process of data analysis as both the ST and the TT were displayed on the log space. The STs and the students' TTs were analyzed to discover the different theme markedness used in the STs and TTs.

\section{FINDINGS AND DISCUSSIONS \\ Similarities between the ST and the TTs}

Based on the data analysis, it was found that there were similarities and differences between the theme markedness used in the source text (ST) and in the target texts (TTs) produced by the student translators. As presented in Figure 1, simple unmarked theme (SUT) was the theme most frequently used in both the STs and the TTs, while multiple marked theme (MMT) was the least frequent. In addition, both the ST and the TTs were composed of more multiple unmarked themes (MUT) than simple marked themes (SMT).

This finding indicates that the students, in terms of theme markedness, tended to follow the ST style; in other words, they were unable to reveal typical theme characteristics of Indonesian news item text through their translation. As a matter of fact, marked themes (composed of circumstances or processes) are commonly used in the clauses of Indonesian news item text because one of its characteristics is specifying 'where' and 'when' the event presented took place (Simbolan, 2006, p. 89). Such information is usually situated at the beginning of a clause, i.e. at the theme position. In addition, the frequent use of marked themes can serve as the medium presenting the flow of information in a news, particularly in showing where and when the event took place. This is in line with Gunawan and Aziza's (2017, p. 420) finding showing that marked themes have an important role in moving the readers from one phase of the story to the next. The same idea is argued by Butt, Fahey, Feez and Yallop (2000) who stated that the use of marked themes can 
avoid monotonous use of subject in the text and highlight particular points of circumstances. Therefore, although they are less frequently used compared to unmarked themes, the gap between them should not be too wide. Even Rosa (2007, p. 64) found that Indonesian newspaper editorials are characterized by the frequent use of marked themes when showing their disagreement over the issue presented. This emphasizes the important role of marked themes in Indonesian news item texts.

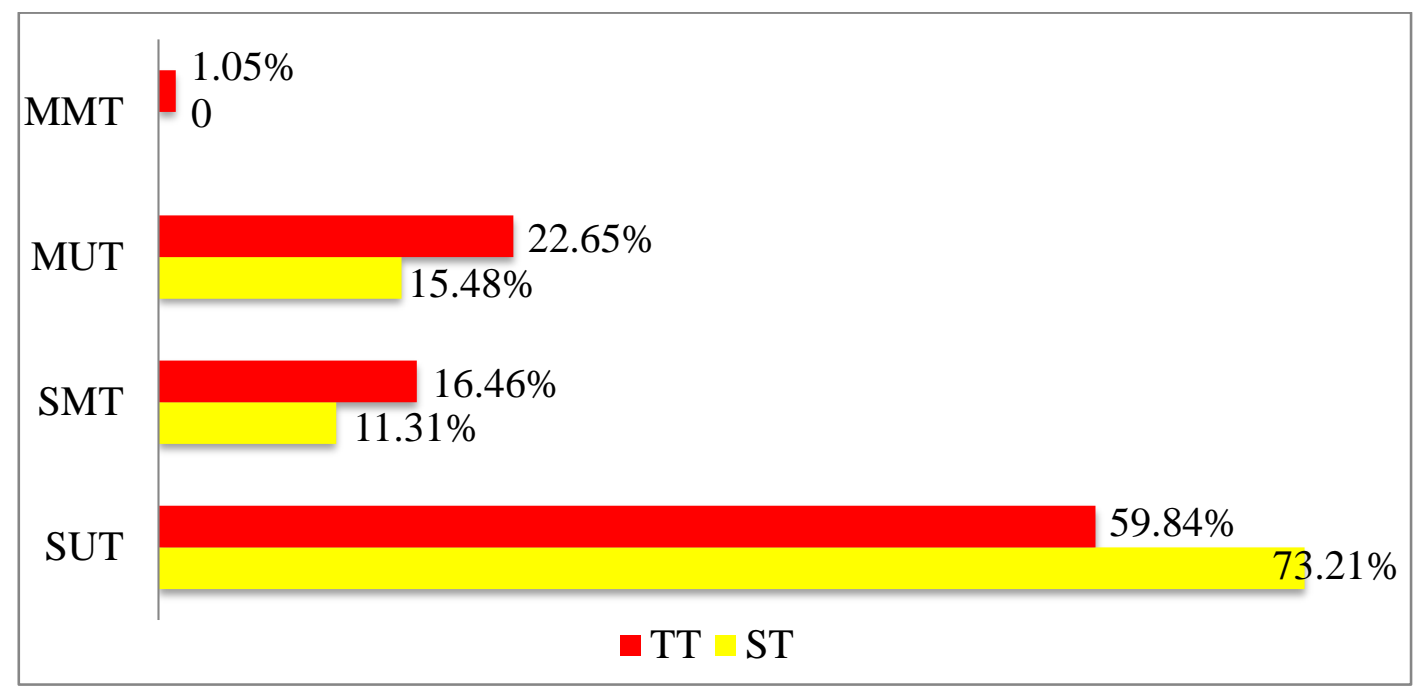

Figure 1. Theme markedness in the STs and the Students' TTs

The lack of ability of the students to reveal the typical characteristics of Indonesian news item text in terms of its theme markedness through their translation is caused by their personality type in translation reflected in their TTs. Their TT clauses showed that they possessed sensing personality in the sense that they tended to dislike problem solving in translation, especially the problems of which they had no prior experience. The data in (1) show one of the students' clauses indicating a weakness in problem solving.

(1) ST : Some users claimed on social media that their accounts had even gone into the red.

$\mathrm{TT}(\mathrm{S} 2)$ : Beberapa pengguna mengaku lewat media sosial bahwa akun mereka bahkan telah menjadi merah.

The decision of Student 2 to provide 'pengguna' as the equivalent of the ST 'users' indicates his unwillingness to search for the right equivalence. The word 'users' literally means 'pengguna' in the TL. It, however, may have a variety of equivalents in the TL depending on the context. Referring to its context, bank account users, opting for 'pengguna' as the equivalent of 'users' is not the right decision because it is too general as it can refer to "vehicle users", "mobile phone users", "language users" and so forth. Therefore, the best equivalent for the word 'users' in this context is 'nasabah'(customer), a specific term in Indonesian banking terminology. As the text translated is a news item text that informs events to the readers, translators should have intuitive personality using their innovative thoughts (Myers et al., 1998) before deciding the best equivalent for certain specific terms. In their research,
Shaki and Khoshsaligheh (2017) found that the participants with intuitive and feeling personality types performed better than their counterparts with sensing personality type in translation of the informative text. In addition, this is in line with the purpose of applying textual metafunction in translation requiring translators to find the right equivalent for the right context by referring to its textual function.

\section{Differences between the ST and the TTs}

Despite their similarities, there were also differences between the ST and the students' TTs. The finding presented in Table 1a and $1 \mathrm{~b}$ showed that the STs were respectively composed of 24 clauses and 21 clauses distributed between three types of theme markedness, while almost all of the students had more clauses in their TTs distributed between four types of theme markedness. Only did two students have the same number of clauses with the ST in Table 1a and one student in Table 1b. Student 7, for example, had 30 clauses, six clauses more than the total number of ST clauses in Table 1a. This indicates that the students' TTs were composed of clauses containing a smaller number of words; in other words, their clauses are short, and short clauses are typically the type of clauses found in Indonesian news item texts (Dewabrata, 2004). Besides, short clauses facilitate the TT readers' understanding of the text. This finding supports Richards, Platt, and Platt (1992, p. 306) stating that the average length of clauses is one of the factors determining the readability of a text in addition to the number of new words contained and the grammatical complexity of the language used in the text. 
Table 1a. The types and frequency of theme markedness in the ST and in the Students' TTs (Text 1)

\begin{tabular}{|c|c|c|c|c|c|c|c|c|c|c|c|c|c|c|c|c|c|}
\hline \multirow{3}{*}{ No. } & \multirow{3}{*}{$\begin{array}{c}\text { Types of } \\
\text { Theme } \\
\text { Markedness }\end{array}$} & \multicolumn{16}{|c|}{ Frequency } \\
\hline & & \multirow{2}{*}{ ST } & \multicolumn{15}{|c|}{ TTs } \\
\hline & & & S1 & S2 & S3 & S4 & S5 & S6 & S7 & S8 & S9 & S10 & S11 & S12 & S13 & S14 & S15 \\
\hline 1 & SUT & 18 & 11 & 19 & 12 & 15 & 13 & 12 & 18 & 19 & 17 & 17 & 19 & 19 & 16 & 16 & 16 \\
\hline 2 & SMT & 2 & 6 & 4 & 5 & 3 & 4 & 6 & 5 & 6 & 7 & 5 & 4 & 3 & 5 & 4 & 5 \\
\hline 3 & MUT & 4 & 7 & 5 & 6 & 6 & 11 & 11 & 7 & 4 & 5 & 7 & 5 & 7 & 6 & 9 & 8 \\
\hline \multirow[t]{2}{*}{4} & MMT & 0 & 1 & 0 & 1 & 0 & 0 & 0 & 0 & 0 & 0 & 0 & 0 & 0 & 1 & 0 & 0 \\
\hline & Total & 24 & 25 & 28 & 24 & 24 & 28 & 29 & 30 & 29 & 29 & 29 & 28 & 29 & 28 & 29 & 29 \\
\hline
\end{tabular}

Table 1b. The types and frequency of theme markedness in the ST and in the Students' TTs (Text 2)

\begin{tabular}{|c|c|c|c|c|c|c|c|c|c|c|c|c|c|c|c|c|c|}
\hline \multirow{3}{*}{ No. } & \multirow{3}{*}{$\begin{array}{c}\text { Types of } \\
\text { Theme } \\
\text { Markedness }\end{array}$} & \multicolumn{16}{|c|}{ Frequency } \\
\hline & & \multirow{2}{*}{ ST } & \multicolumn{15}{|c|}{ TTs } \\
\hline & & & S1 & S2 & S3 & S4 & S5 & S6 & S7 & S8 & S9 & S10 & S11 & S12 & S13 & S14 & S15 \\
\hline 1 & SUT & 15 & 16 & 16 & 17 & 15 & 13 & 15 & 16 & 14 & 14 & 14 & 17 & 17 & 12 & 14 & 16 \\
\hline 2 & SMT & 3 & 4 & 4 & 5 & 3 & 4 & 3 & 3 & 4 & 5 & 4 & 4 & 4 & 5 & 4 & 5 \\
\hline 3 & MUT & 3 & 3 & 4 & 4 & 5 & 5 & 7 & 7 & 4 & 4 & 3 & 6 & 4 & 8 & 5 & 5 \\
\hline 4 & MMT & 0 & 0 & 1 & 1 & 0 & 0 & 0 & 1 & 0 & 1 & 0 & 0 & 0 & 1 & 0 & 0 \\
\hline & Total & 21 & 23 & 25 & 27 & 23 & 22 & 25 & 27 & 22 & 24 & 21 & 27 & 25 & 26 & 23 & 26 \\
\hline
\end{tabular}

In addition to the readability purpose, writing more clauses can also serve as the indicator of lexical richness in a text, characterizing a news item text from other text types. Van Gijsel, Speelman and Geeraerts (2006, p. 958) argued that a news item text has richer lexical items than the other types of text for comprising more formal and prepared components.

The larger number of clauses in the students' TTs is the result of the clause shifts performed by the students. One example of this can be seen in (2).

(2) ST : The 165 year-old BPI counts Philippines conglomerate Ayala and Singapore sovereign wealth fund GIC among its major shareholders. (Text 1)

TT(S7) : BPI bank berumur 165 tahun (i) (Dia) menghitung (ii) konglomerat Filipina Ayala dan dana kekayaan kedaulatan Singapura GIC adalah di antara pemegang saham utamanya. (iii)

The ST in (2) is composed of only one clause represented by one process (counts), while the TT written by Student 7 is composed of three clauses represented by three processes; berumur (year-old), menghitung (counts), and adalah (are). The ST phrase 'The 165 year-old BPI' was rank-shifted into a clause in the TT 'BPI bank berumur 165 tahun'. The shift was motivated by the student's effort to make the TT more natural to the TT readers as the structure of the ST was not common in the TL structure. The next shift was when she rank-shifted the TT process 'counts' - realized as a verbal group - into a clause in the TT '(Dia) menghitung' containing an implicit topical theme 'Dia'(she/he/it). The topical theme was implicit since the first clause and the second clause had the same topical theme. The third shift occurred when she again rank-shifted the nominal group of the ST rheme 'Philippines conglomerate Ayala and Singapore sovereign wealth fund GIC among its major shareholders' into a clause in the TT 'konglomerat Filipina Ayala dan dana kekayaan kedaulatan Singapura GIC adalah di antara pemegang saham utamanya.'.

In addition, the finding presented in Table $1 \mathrm{a}$ and $1 \mathrm{~b}$ also showed that the students' TTs contained more marked theme clauses than did the STs. The different frequency between the use of marked themes in the STs and the TTs (displayed in Figure 2) showed that the STs were composed, on average, of two and three marked theme clauses respectively, while the TTs were composed, on average, of five marked theme clauses (simple and multiple marked themes).

In addition to clause shifts, the difference was also caused by the shifts of theme elements. The examples in (3) and (4) show the theme markedness shift done by the Students in their TTs.

The ST theme in (3) was 'they' belonging to the participant; meanwhile, the TT theme was another transitivity element, circumstance 'sekarang'(now). The ST theme was shifted into the TT rheme element 'mereka'(they), while the ST circumstance 'now' which used to be the rheme element was shifted into the TT theme 'sekarang'(now). The shift was mainly motivated by the effort of Student 9 to change the TT point of view. The TT focused more attention on 'when' the event took place, rather than 'who' did the event. In addition, moving the time circumstance to the theme position emphasized the important role of time in presenting an event. Thus, the shift taking place in the example in (3) was the shift from an unmarked to a marked theme. In addition, the theme markedness shift can also be realized in the shift from a marked theme to an unmarked theme as in (4). 


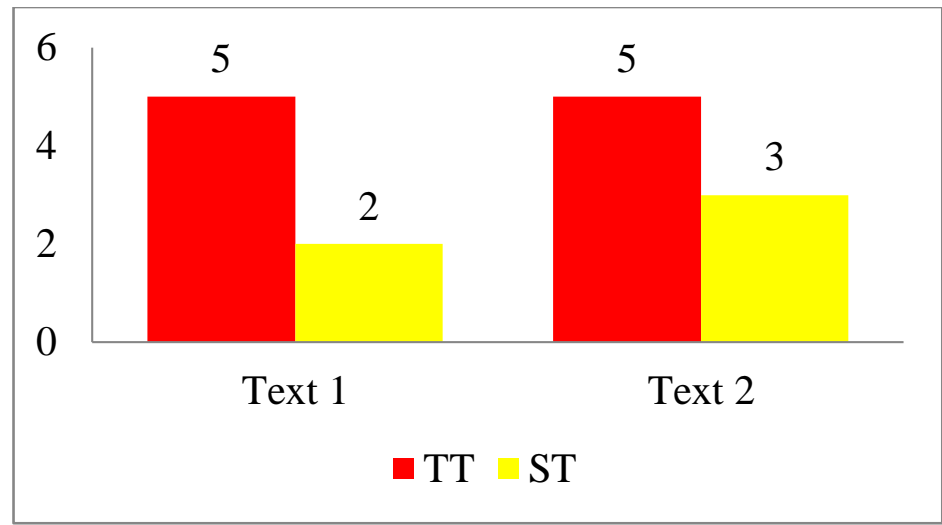

Figure 2. The average number of marked themes of the ST and the Students' TTs

(3) ST

\begin{tabular}{|c|c|}
\hline they & now can't check their accounts to see \\
\hline Participant & \multirow{3}{*}{ Rheme } \\
\hline Topical & \\
\hline SUT & \\
\hline
\end{tabular}

TT (S9) :

\begin{tabular}{|c|c|}
\hline & ididak bisa mengecek akun mereka untuk melihat \\
\hline Circumstance & \multirow{3}{*}{ Rheme } \\
\hline Topical & \\
\hline SMT & \\
\hline
\end{tabular}

(4) ST

\begin{tabular}{|l|l|} 
commented & Geoff Blaber from the CCS Insight consultancy \\
\hline Process & \\
\cline { 1 - 1 } Topical & Rheme \\
\hline SMT & \\
\hline
\end{tabular}

TT (S11) :

Geoff Blaber, konsultan CCS Insight
\begin{tabular}{|l|c|}
\hline Participant & mengomentari \\
\hline Topical & Rheme \\
\hline SUT & \\
\hline
\end{tabular}

The ST theme in (4) was 'commented' having a function of the clause process; meanwhile, the TT theme was a different transitivity element, participant 'Geoff Blaber, konsultan CCS Insight'. The ST theme was shifted into the TT rheme element 'mengomentari'(commented), while the ST participant 'Geoff Blaber from the CCS Insight consultancy' which used to be the rheme element was shifted into the TT theme. The shift changed the TT point of view as it put an emphasis on 'who did the process', instead of on 'what process was taking place'. Thus, the shift taking place in the example in (4) was the shift from a marked theme to an unmarked theme.

Furthermore, the results of the analysis show that, unlike the TTs, all of the ST marked themes in Text 1 were composed of circumstances as in (5) and (6).

The ST circumstance in (5) 'Over the next few hours' was the equivalent of the TT (written by Student 13) circumstance 'Dalam beberapa jam ke depan'. Both of the ST and TT circumstances were labeled as the clause themes. Similarly, the ST circumstance in (6) 'In a statement posted on Twitter', equivalent to the TT circumstance 'Dalam sebuah pernyataan melalui Twitter', both also served as the theme. The examples in (5) and (6) showed that all of the ST's circumstances as the themes were kept in the students' TTs.

However, in Text 2, it was found that two of the ST marked themes were composed of a process, one of which is shown in (7).

The ST theme in (7) was composed of a process indicating that the clause theme was an SMT. The ST process 'noted', equivalent to ' $k a t a$ ' (said/noted) in the TT written by Student 15, also served as the TT theme, meaning that the TT kept the ST thematic structure.

Unlike the STs, many TT themes were composed of processes. In Text 1, for example, several ST unmarked themes were shifted to marked themes in the TTs by moving the process into the theme position as shown in (8). 
(5) ST

"Over the next few hours,
\begin{tabular}{|l|l|}
\hline Circumstance & we are making sure \\
\cline { 1 - 1 } Topical & Rheme \\
\hline SMT & \\
\hline
\end{tabular}

TT (S13)

\begin{tabular}{|l|c|}
\multicolumn{1}{|c}{ "Dalam beberapa jam ke depan, } & kami akan memastikan \\
\hline Circumstance & Rheme \\
\cline { 1 - 1 } Topical & \\
\hline SMT & \\
\hline
\end{tabular}

(6) ST

\begin{tabular}{|c|c|}
\hline In a statement posted on Twitter, & BPI said \\
\hline Circumstance & \multirow{3}{*}{ Rema } \\
\hline Topical & \\
\hline SMT & \\
\hline
\end{tabular}

TT (S13) :

Dalam sebuah pernyataan melalui Twitter,
\begin{tabular}{|l|c|}
\hline Circumstance & RPI mengatakan \\
\cline { 1 - 1 } Topical & Rheme \\
\hline SMT
\end{tabular}

(7) ST

\begin{tabular}{|l|c|}
\multicolumn{1}{l|}{ noted } & \\
\hline Process & \\
\cline { 1 - 1 } Topical & Rheme \\
\cline { 1 - 1 } SMT & \\
\hline
\end{tabular}

TT (S15)

\begin{tabular}{|l|c|}
\multicolumn{1}{l|}{ kata } & Ian Fogg, konsultan IHS Markit. \\
\hline Process & Rheme \\
\cline { 1 - 1 } Topical & RMT \\
\hline
\end{tabular}

(8) $\mathrm{ST}$

$\mathrm{He}$

\begin{tabular}{|c|c|}
\hline Participant & \multirow{3}{*}{ Rheme } \\
\hline Topical & \\
\hline SUT & \\
\hline
\end{tabular}

$\mathrm{TT}(\mathrm{S} 14) \quad$ :

\begin{tabular}{|c|c|}
\hline kata & beliau. \\
\hline Process & \multirow{3}{*}{ Rheme } \\
\hline Topical & \\
\hline SMT & \\
\hline
\end{tabular}

The TT written by Student 14 was composed of SMT in which the process ' $k a t a$ ' (equivalent with 'said' in the ST) served as the clause theme. Meanwhile, the ST was composed of SUT in which the participant 'he' served as the clause theme. One of the characteristics of a news item text is the presence of both direct and indirect speech which is written together with a verbal process. In the Indonesian news item text, the verbal process in such a context usually precedes its participant, resulting in a marked theme. The use of process as the theme clause in the $\mathrm{TT}$ indicates that
Indonesian news item texts view verbal processes as the starting point of the message containing a resource of information. The difference in the elements of marked themes between the STs and the TTs is presented in Table $2 \mathrm{a}$ and $2 \mathrm{~b}$.

As shown in Table 2a, all of the students' TTs contain a process as the element of marked themes. One of the students, Student 9, even used process four times as the marked theme elements of the TT clauses. On the other hand, none of the ST theme elements was composed of a process. Although the ST in Table $2 \mathrm{~b}$ 
contains a process as the marked theme element, the TTs are composed of a larger number of processes as the theme. The findings displayed in Table $2 a$ and $2 b$ also show that processes and circumstances are two essential elements of marked theme in presenting newsworthy event in Indonesian news item texts.

Table 2a. The elements of marked themes of the ST and the TTs (Text 1)

\begin{tabular}{|c|c|c|c|c|c|c|c|c|c|c|c|c|c|c|c|c|c|}
\hline \multirow{3}{*}{ No. } & \multirow{3}{*}{$\begin{array}{l}\text { Marked } \\
\text { Theme } \\
\text { Elements }\end{array}$} & \multicolumn{16}{|c|}{ Frequency } \\
\hline & & \multirow{2}{*}{ ST } & \multicolumn{15}{|c|}{ TT } \\
\hline & & & S1 & S2 & S3 & S4 & S5 & S6 & S7 & S8 & S9 & S10 & S11 & S12 & S13 & S14 & S15 \\
\hline 1 & Process & 0 & 2 & 2 & 2 & 1 & 1 & 2 & 3 & 3 & 4 & 3 & 2 & 1 & 3 & 2 & 3 \\
\hline \multirow[t]{2}{*}{2} & Circumstance & 2 & 5 & 2 & 4 & 2 & 3 & 4 & 2 & 3 & 3 & 2 & 2 & 2 & 3 & 2 & 2 \\
\hline & Total & 2 & 7 & 4 & 6 & 3 & 4 & 6 & 5 & 6 & 7 & 5 & 4 & 3 & 6 & 5 & 5 \\
\hline
\end{tabular}

Table 2b. The elements of marked themes of the ST and the TTs (Text 2)

\begin{tabular}{|c|c|c|c|c|c|c|c|c|c|c|c|c|c|c|c|c|c|}
\hline \multirow{3}{*}{ No. } & \multirow{3}{*}{$\begin{array}{l}\text { Marked } \\
\text { Theme } \\
\text { Elements }\end{array}$} & \multicolumn{16}{|c|}{ Frequency } \\
\hline & & \multirow{2}{*}{ ST } & \multicolumn{15}{|c|}{ TT } \\
\hline & & & S1 & $\mathbf{S 2}$ & S3 & S4 & S5 & S6 & S7 & S8 & S9 & S10 & S11 & S12 & S13 & S14 & S15 \\
\hline 1 & Process & 2 & 3 & 3 & 4 & 2 & 2 & 2 & 2 & 2 & 4 & 3 & 2 & 3 & 3 & 2 & 3 \\
\hline 2 & Circumstance & 1 & 1 & 2 & 2 & 1 & 1 & 1 & 1 & 2 & 2 & 1 & 2 & 1 & 3 & 2 & 2 \\
\hline & Total & 3 & 4 & 5 & 6 & 3 & 3 & 3 & 3 & 4 & 6 & 4 & 4 & 4 & 6 & 5 & 5 \\
\hline
\end{tabular}

\section{CONCLUSIONS}

Based on the research findings, it is concluded that Indonesian and English news item texts share a small number of similarities as most of their clauses are composed of simple marked themes (SMT) but the similarities are outweighed by a large number of differences. First, the Indonesian news item texts are different from English news item texts in terms of their theme markedness reflected through the TTs produced by the students. Second, the Indonesian news item texts typically have more marked theme clauses than do the English news item texts. Third, the marked theme clauses of the Indonesian news item texts are composed of process and circumstance in equal number, while the marked theme clauses of English news item texts are dominated by circumstances. Such differences obviously show that a text is influenced by the culture where it is produced. In addition to similarities and differences of the ST and the TT elaborated above, it is also concluded that a good TT can show its independence by not imitating the style and the structure of the ST.

These research findings have several limitations. First, this study took only two source texts as the data which might influence the finding of the research. Second, the finding on the typical characteristics of Indonesian news item text was based on the TTs produced by student translators. Third, the translation task was done in a classroom which might affect the students' mental state.

Based on the conclusions and limitations elaborated earlier, several suggestions are recommended. First, translators should carefully look at the theme markedness in organizing the TT clauses because it can show the typical characteristics of the TT. Second, it is suggested to other researchers to take more texts as the data to strengthen the research findings. Third, it is suggested to other researchers to take professional translators as the research participants to get a better quality of the TT.

\section{REFERENCES}

Akbari, A., \& Segers, W. (2017). Diverse personality traits and translation quality. Trans-kom, 10(2), 242-270.

Bell, R. T. (1991). Translation and translating: Theory and practice. London: Longman.

Brislin, R. W. (1976). Translation: Application and research. New York: Gardner Press Inc.

Butt, D., Fahey, R., Feez, S., \& Yallop, C. (2000). Using functional grammar: An explorer's guide ( $2^{\text {nd }}$ ed.). Sydney: National Centre for English Teaching and Research, Macquarie University.

Chesterman, A. (2006). Interpreting the meaning of translation. In M. Suominen, A. Arppe, A. Airola, O. Heinämäki, M. Miestamo, U. Määttä, J. Niemi, K. K. Pitkänen \& K. Sinnemäki (Eds.), A man of measure: Festschrift in honour of Fred Karlsson on his 60th birthday (pp. 3-11). Turku: Linguistic Association of Finland.

Chesterman, A., \& Wagner, E. (2002). Can theory help translators? A dialogue between the Ivory Tower and the Wordface. Manchester: St. Jerome Publishing.

Dewabrata, A. M. (2004). Kalimat jurnalistik. Jakarta: PT Kompas Media Nusantara.

Dragsted, D., Mees, I. M., \& Hansen, I. G. (2011). Speaking your translation: Students' first encounter with speech recognition technology. Translation \& Interpreting, 3(1), 10-43.

Eggins, S. (1994). An introduction to systemic functional linguistics. London: Pinter.

Gunawan, W., \& Aziza, F. (2017). Theme and thematic progression of undergraduate thesis: Investigating meaning making in academic writing. Indonesian Journal of Applied Linguistics, 7(2), 413-424.

Halliday, M. A. K. (1985). An introduction to functional grammar. London: Arnold.

Halliday, M. A. K. (1992). Language theory and translation practice. Rivista internazionale di tecnica della traduzione, 0, 15-25. 
Halliday, M. A. K. (1994). An introduction to functional grammar ( $2^{\text {nd }}$ ed.). London: Arnold.

Halliday, M. A. K. (2002). Language structure and language function. In J. Webster (Ed.), On grammar: The collected works of M. A. K. Halliday. Vol. 1 (pp. 173-195). London: Continuum.

Halliday, M. A. K., \& Matthiessen, C. M. I. M. (2004). An introduction to functional grammar ( $3^{\text {rd }} \mathrm{ed}$.) London and New York: Routledge.

Hatim, B. (2001). Teaching and researching translation. Harlow: Pearson Education.

Jalilifar, A. (2009). Thematic development in English and translated academic texts. Journal of Language \& Translation, 10(1), 81-111.

Larson, M. L. (1984). Meaning-based translation: A guide to crosslanguage equivalence. Lanham: University Press of America.

Ma, Y., \& Wang, B. (2016). A review of systemic functional translation studies from an interpersonal perspective. International Forum of Teaching and Studies, 12(1), 36-41.

Martin, J. R., Matthiessen, C. M. I. M., \& Painter, C. (1997). Deploying functional grammar. Beijing: Commercial Press.

Mellinger, C. D., \& Hanson, T. A. (2017). Quantitative research methods in translation and interpreting studies. New York: Routledge.

Munday, J. (2008). Introducing translation studies: Theories and applications ( $2^{\text {nd }}$ ed.). New York, NY: Routledge.

Myers, I. B., Myers K. D., \& Kirby, L. K. (1998). Introduction to type: A guide to understanding your results on the Myers-Briggs type indicator. California, CA: Consulting Psychologists.

Newmark, P. (1981). Approaches to translation. Oxford: Pergamon Press.

Nida, E. A., \& Taber, C. (1969). The theory and practice of translation. Leiden: Brill.
Nurlela, Sofyan, R., Gustianingsih, \& Rosa, R. N. (2017). Theme characteristics of Indonesian narrative text. A paper presented at Persidangan Antarbangsa Linguistik Bahasa Melayu on 16-17 November 2017, Penang, Malaysia.

Ordudari, M. (2008). Good translation: Art, craft, or science? Translation Journal. Retrieved October 15th, 2017 from http://translationjournal.net/journal/43theory.htm.

Pourgharib, B., \& Dehbandi, Z. (2013). The impact of translator's personality on translation quality of narrative texts. International Journal of Basic Sciences \& Applied Research, 2(4), 417-422.

Richards, J. C., Platt, J., \& Platt, H. (1992). Longman dictionary of language teaching and applied linguistics. London: Longman.

Rosa, R. N. (2007). Analisis fungsi tekstual dalam surat kabar harian Haluan. Lingua Didaktika, 1(1), 5665.

Shaki, R., \& Khoshsaligheh, M. (2017). Personality type and translation performance of Persian translator trainees. Indonesian Journal of Applied Linguistics, 7(2), 360-370.

Simbolan, P. T. (2006). Vademekum wartawan ( $5^{\text {th }}$ ed.). Jakarta: KPG.

Van Gijsel, S., Speelman, D., \& Geeraerts, D. (2006). Locating lexical richness: A corpus linguistic, sociovariational analysis. JADT 2006. Proceedings of 8th International Conference on Textual Data Statistical Analysis. (pp. 961-971) Besançon: Presses Universitaires de Franche-Comté.

Wilss, W. (1982). The science of translation. Stuttgart: Gunter Narr verlag Tubingen.

Yallop, C. (1987). The practice and theory of translation. In R. Steele \& T. Threadgold (Eds.), Language topics: Essays in honour of Michael Halliday (Vol. 1) (pp. 347-351). Amsterdam: John Benjamins. 